\title{
Theofilos
}

A Nordic open access journal in Theology, Philosophy and Culture

Published by NLA University College - in partnership with Johannelund School of Theology

Available at www.theofilos.no

\section{Responsible Apologetics: Philosophical Reflections on John Warwick Montgomery's Always Be Ready: A Primer on Defending the Christian Faith (1517 Publishing, 2018)}

\author{
Peter S. Williams \\ Assistant Professor in Communication and Worldviews, NLA University College \\ peterswilliams@gmail.com
}

John Warwick Montgomery (b. 1931) has been a major voice in Christian apologetics since the 1960's. Described as 'one of the pioneers of historical apologetics' by philosopher and apologist Norman L. Geisler ${ }^{1}$, Montgomery is literally a textbook example of the 'evidentialist' school of apologetics. ${ }^{2}$ In books such as History and Christianity (Bethany House, 1964) he updated the tradition of 'legal apologetics' stemming from eighteenth century works like Thomas Sherlock's The Trial of the Witnesses of the Resurrection of Jesus Christ (1729)3, defending the New Testament gospels as at least largely trustworthy records on the basis of general criteria for historical and textual reliability. This methodology has a continuing relevance as a supplement to 'minimal facts' approach to historical apologetics pioneered by evidentialist Gary R. Habermas, ${ }^{4}$ and Montgomery's influence can be seen in the work of many modern apologists, including Norman L. Geisler, Josh and Sean McDowell, J.P. Moreland, Lee Strobel and J. Warner Wallace. ${ }^{5}$

The author of over a hundred journal articles, and author or editor of over fifty books, Montgomery has publicly debated a series of significant figures including atheist Madalyn Murray O'Hair, deathof-God advocate Thomas Altizer, and situation-ethicist Joseph Fletcher. Montgomery has also made significant contributions to forging links between Christian faith and a variety of academic fields, such as the philosophy of history, ${ }^{6}$ literary studies $^{7}$ and jurisprudence. ${ }^{8}$ An Emeritus Professor of the University of Bedfordshire, Montgomery is also the director of the International Academy of Apologetics, Evangelism \& Human Rights in Strasbourg, France.

Montgomery is an ordained Lutheran clergyman, an English barrister, an avocet an Barreau de Paris, France, and a lawyer admitted to practice before the Supreme Court of the United States. He obtained acquittals for the 'Athens 3' missionaries on charges of proselytism at the Greek Court of Appeals in 1986 and won the leading religious liberty cases of Larissis v. Greece and Bessarabian Orthodox Church v. Modova before the European Court of Human Rights. ${ }^{9}$

I have personally benefitted from reading several of Montgomery's books over the years and have often quoted his work with approval in my own writing. I was therefore excited to read his recent, popular-level book treating a broad range of apologetic issues in the form of a 'primer' written 'to show how easy it is to do apologetics responsibly.' ${ }^{10}$. First published as 
Defending the Faith In A Messy World (1517 the Legacy Project, 2017), John Warwick Montgomery's Always Be Ready: A Primer on Defending the Christian Faith (1517 Publishing, 2018) proclaims itself to be a 'simple layman's primer on defending the Christian faith'11 aimed at 'the fledgling apologist'. ${ }^{12}$ In this paper I offer a critical review of Always Be Ready in order to draw some lessons about responsible apologetics.

\section{Defining 'Responsible Apologetics'}

What does it mean to do Christian apologetics responsibly? According to Alister McGrath: 'Apologetics is both a science and an art. It is not just about knowledge; it is about wisdom.'13 That is, Christian apologetics is about wisely communicating and advocating truth in love (Ephesians 4:15). Christian apologetics is an art as well as a science because it's a way of loving one's neighbour; and one's neighbour is a holistic person designed for spiritual fulfilment, not a computer algorithm for disinterestedly calculating the best worldview. Hence Christian apologetics may be defined as the art and science of persuasively communicating and advocating Christian spirituality across spiritualties, through the responsible use of rhetoric, as being objectively reasonable and/or true, good and beautiful.14 This being so, one might suggest that doing Christian apologetics responsibly requires the rhetorically wise (artful and loving) communication and advocation of truth, an undertaking that includes (but isn't limited to) the communication of sound arguments in a style and with a level of sophistication appropriate for one's audience.

\section{Montgomery's Argumentative Methodology}

According to Always Be Ready, doing apologetics 'responsibly' appears to be primarily a matter of adopting a particular argumentative methodology, one modelled on the court room and grounded in an epistemology that emphasizes empirical observation and legal-style reasoning from empirical data. As Kenneth D. Boa and Robert M. Bowman Jr. observe, Montgomery's 'advocacy of empirical method is more thoroughgoing than perhaps any other noted evidentialist . . .', though he (rightly) 'denies that all knowledge is gained solely through inductive reasoning . ..'15

Montgomery advocates this approach with a polemical tone that creates a rod for his own back, complaining that 'Christian philosophers have convinced the church that only the metaphysically acute can properly defend the Christian faith'. ${ }^{16}$ While one doesn't have to be 'metaphysically acute' to answer the call to 'always being prepared to make a defense to anyone who asks you for a reason for the hope that is in you . . . with gentleness and respect' (1 Peter 3:15, ESV), it can only be beneficial. It certainly behooves the professional apologist (whether they are a professional philosopher or not), to be as 'metaphysically acute' as they can reasonably manage to be.

Despite his first degree being in classics and philosophy (at Cornell University), Montgomery gives metaphysics short shrift, stating that: 'because of human limitations and the vast extent of the cosmos, no amount of sincere huffing and puffing will produce a metaphysically compelling, comprehensive explanation of reality.' 17 The description of metaphy- 
sics as 'huffing and puffing' seems prejudicial, and I've no idea how the size of the cosmos is meant to impact the difficulty of giving a 'compelling, comprehensive explanation of reality' in metaphysical terms. Montgomery doesn't say what would be wrong with advancing a metaphysic as simply the best, most compelling and comprehensive explanation of reality.

Each short chapter of Always be Ready is accompanied by a cartoon, a feature no doubt intended to make the book more reader friendly. One cartoon portrays a philosophy professor saying: 'Uh... Heh Heh, I do not believe in Absolutes'.18 The impression created by this cartoon is, of course, a false generalization (as a philosopher, I can testify to my own belief in absolutes).

Montgomery grumbles that 'philosophers never have to come to definitive conclusions'. ${ }^{19}$ If we apply this statement to individual philosophers, it is false. If we apply it to philosophers as a group, it remains something of a false generalization, and one that could be applied to scientists and theologians as well (whose work, it must be remembered, is unavoidably influenced by philosophy).

Montgomery asserts that: '(One of the problems with professional philosophers, not so incidentally, is that they continually try to make cosmic assertions without bothering to investigate cosmic facts.)'20 This is yet another false generalization. As James K. Beilby and Paul Rhodes Eddy report:

It is no longer merely New Testament scholars and historians who are wading into the rushing waters of the quest [for the historical Jesus], but an entire cadre of interdisciplinary explorers, each bringing their own distinctive disciplinary methods, tools and insights to the historical study of Jesus and the Gospels. ${ }^{21}$

In particular, they note that: 'in recent times one can find a variety of philosophers and philosophical theologians weighing in on relevant matters.' 22 I have myself been privileged to publish or contribute to several books on the historical Jesus. ${ }^{23}$ Philosophers who have made notable contributions to this interdisciplinary quest include: William Lane Craig, Stephen T. Davis, C. Stephen Evans, Gary R. Habermas, Lydia McGrew and Richard Swinburne. ${ }^{24}$

A true philosopher may be defined as someone dedicated to the wise pursuit and dissemination of true answers to significant questions through the practice of good intellectual habits. ${ }^{25}$ They seek to know and to defend those answers by thinking carefully and arguing well. True Christian spirituality is greatly concerned with wisdom, truth and goodness; so, its unsurprising that philosophical attitudes and activities, and the tools and virtues they require, are integral to Christian ministries of teaching (e.g. preaching) and apologetics (i.e. persuasive evangelism). While none of this means Christians should study philosophy formally, Christians should heed the call 'to work out the salvation that God has given you with a proper sense of awe and responsibility' (Philippians 2:12)26, and philosophical thinking is an indispensable component of such faithful work. ${ }^{27}$

Since philosophy is unavoidable, it is obviously wiser to have a studied opinion rather than an unstudied opinion. As C.S. Lewis said: 'Good philosophy must exist, if for no other reason, because bad philosophy needs to be answered.'28 In particular, anyone venturing to teach Christian 
apologetics would be especially well advised to develop a reasonable degree of familiarity with the basics of philosophical rhetoric, including logic. For as John Wesley counselled:

Some knowledge of the sciences also, is, to say the least . . . expedient. Nay, may we not say, that the knowledge of one ... is even necessary next, and in order to, the knowledge of the Scripture itself? I mean logic. For what is this, if rightly understood, but the art of good sense, of apprehending things clearly, judging truly, and reasoning conclusively? What is it, viewed in another light, but the art of learning and teaching; whether by convincing or persuading? What is there, then, in the whole compass of science, to be desired in comparison of it? 29

As Christian philosopher and apologist Douglas Groothuis comments:

In the past few decades Christian philosophers have been mounting an impressive case for Christian truth at the highest levels of philosophy. However, noted apologist John Warwick Montgomery makes the claim that apologetics is not philosophy. He seems to be saying that there is more to defending Christianity than giving abstract logical arguments. There is no disputing that, but every kind of apologetic defence requires rigorous philosophical reasoning, whether it concerns cosmology or historiography or psychology. ${ }^{30}$

Despite giving readers the strong impression that he has a low opinion of philosophy and philosophers, Montgomery boasts about being a 'distinguished research professor of philosophy - with more degrees than a thermometer'. ${ }^{31}$ This statement isn't literally true. ${ }^{32}$ Moreover, Montgomery happily quotes philo- sophers with approval when it suits him, and readily engages in philosophical argumentation. Regrettably, Montgomery displays a lack of metaphysical acumen that rather undermines his book's raison d'être.

\section{Montgomery's Presuppositions}

Montgomery advocates his empiricist epistemology via a critique of 'theological "presuppositionalists"' 33 who 'note that all arguments begin with unprovable presuppositions, so the Christian has every right to start with his or hers.' 34 Montgomery argues as follows:

Philosophically, it is quite true that
all arguments start from unpro-
vable assumptions. But, though all
presuppositions are equal, some are
more equal than others! That is to
say, it is far better to start with pre-
suppositions of method (deductive
logic and inductive method that
can lead to the discovery of truth)
than to begin with presuppositions
of content - that prejudge the natu-
re of the cosmos and cannot in
principle be confirmed or disconfir-
med. 35

What Montgomery seems to mean is that all presuppositions are not equal, that presuppositions are either of content (presuppositions that make truth-claims about the nature of reality, but which cannot in principle be empirically confirmed or disconfirmed), or of method (presuppositions that do not make truthclaims about the nature of the cosmos, but which can lead to the discovery of truth, presumably in combination with non-presuppositional statements of content that have been be empirically confirmed or disconfirmed), and that one should begin with presuppositions of method rather than of content.

However, what Montgomery calls 
'presuppositions of content' are not all equal. Some presuppositions of content cannot in principle be empirically confirmed or disconfirmed, for the simple reason that they are presuppositions of empirical confirmation and disconfirmation. Consider, for example, the belief that the material cosmos exists independently of our empirical perceptions of it. Or the belief that one exists. Or the belief that one has a persistent identity over time. On the other hand, as reformed epistemologists have pointed out, there are 'presuppositions of content' that one may rationally hold without argumentation such as the memory-based belief that one had toast for breakfast - that can in principle be empirically confirmed or disconfirmed.

Furthermore, Montgomery's distinction between presuppositions of content and method is unsustainable. The presuppositions of deductive logic, which Montgomery labels 'presuppositions of method', are truth claims about the nature of reality (including the cosmos), despite the fact that they are not open to empirical confirmation or disconfirmation. For example, to say that a deductive argument is logically valid is to say that if the premises of the argument are true, then reality is such that the conclusion of that argument is necessarily true. Again, to say that the logical law of non-contradiction is true is to say that reality is such that contradictory propositions cannot both be true at the same time and in the same sense. It is to say that the contrary of any true proposition is false (and vice versa). It is to say that nothing self-contradictory has concrete reality. You can talk about square circles, but you can never trip over one; and any empirical evidence that seems to support the existence of a square circle must be rejected as mistaken on pain of irrationality.

\section{The Rise and Fall of Verificationism}

The root cause of Montgomery's epistemological mistakes appears to be a commitment to a naive form of empiricism that's reminiscent of logical positivism, a philosophical movement from the early twentieth century that declared that talk about 'God' was literally meaningless.

This view was popularized by A.J. Ayer's book Language, Truth and Logic (first published in 1936), which 'served as a sort of manifesto for this movement ... The principal weapon employed by Ayer in his campaign against metaphysics was the vaunted Verification Principle of meaning.' ${ }^{36}$ According to the verification principle, the meaning of any statement that isn't true by definition (e.g. $2+2=4$ ) lays in its ability to be empirically verified (at least in principle). In other words, 'Socks exist' is a meaningful statement because you can, at least in principle, verify this (by seeing, hearing, touching, smelling or tasting socks); but 'God exists' is a meaningless statement because you can't, supposedly, verify this (by seeing, hearing, touching, smelling or tasting God). Thus Ayer proclaimed: 'to say that 'God exists' is to make a metaphysical utterance which cannot be either true or false . ..'37 for 'If a putative proposition fails to satisfy [the verification] principle, and is not a tautology, then ... it is metaphysical, and ... being metaphysical, it is neither true nor false but literally senseless.' 38

Several factors conspired to render positivism 'no longer fashionable', ${ }^{39}$ as the noted Catholic philosopher F.C. Copleston declared just two decades after Language, Truth and Logic was first published. For one thing, as Ayer himself admitted: 'If the assertion that there is a god is nonsensical, then the ... assertion that there is no god is equally nonsensical.'40 The same goes for agnosticism; 
and, indeed, although many who embraced positivism were materialists, 'materialism would have to be rejected as nonsense by a strict interpretation of logical positivism.' 41 After all, the mind-independent reality of matter is neither true by definition, nor something that can be empirically verified! Hence, although it was designed to demarcate and promote 'scientific' (empirical) knowledge claims over 'non-scientific' (e.g. metaphysical) knowledge claims, the verification principle acted as a 'universal acid' that ate away the unavoidably philosophical foundations of science itself:

Philosophers soon began to realize ... that the Verification Principle was a double-edged sword. For it would force us to dismiss as meaningful not only theological statements but also a great many scientific statements as well, so that the principle cuts off at the knees science itself, in whose service this weapon had been wielded. As it turns out, physics is filled with metaphysical statements that cannot be empirically verified ... If the ship of scientific naturalism was not to be scuttled, verificationism had to be cut loose. ${ }^{42}$

Given the anti-materialistic and anti-scientific implications of the verification principle, even the irreligious might be tempted to endorse atheist Kai Nielson's common-sense observation: 'Most claims that people make are not scientific; yet they can, for all that, be true or false.' 43 Indeed, Ayer himself later mused:

The very fact that [the verification principle] denied meaning to statements which many people regarded as meaningful could be taken as evidence that it was false. The only answer that could be made to this objection was that the principle was advanced as a stipulative defi- nition. It did not describe how the word 'meaning' was commonly used, but prescribed how it should be. But then why should anyone follow the prescription if its implications were not to his taste? We have, in fact, seen that the verification principle is defective . . . ${ }^{44}$

As atheist Luke Muehlhauser comments: 'in the 1950s and 60s, certain (atheistic) philosophers provided powerful criticisms of logical positivism, which led to its demise.'45 For example, in a paper originally delivered at a meeting of the Oxford Socratic Club in the summer of 1950, Antony Flew pointed out that:

To assert that such and such is the case is necessarily equivalent to denying that such and such is not the case. Suppose then that we are in doubt as to what someone who gives vent to an utterance is asserting, or suppose that, more radically, we are sceptical as to whether he is really asserting anything at all, one way of trying to understand (or perhaps it will be to expose) his utterance is to attempt to find what he would regard as counting against, or as being incompatible with, its truth. For if the utterance is indeed an assertion, it will necessarily be equivalent to a denial of the negation of the assertion. And anything which would count against the assertion ... must be part of (or the whole of) the meaning of the negation of that assertion. And to know the meaning of the negation of an assertion is, as near as makes no matter, to know the meaning of that assertion. ${ }^{46}$

In other words, one can show that a theological utterance has meaning without showing that it is verifiable, by showing that it is falsifiable. As Flew later explained: 
My primary purpose in 'Theology and Falsification' was to spice up the bland dialogue between logical positivism and the Christian religion and to set discussion between belief and unbelief upon different and more fruitful lines ... I was not saying that statements of religious belief were meaningless. 47

That is, Flew wasn't setting up falsifiability as an alternative mirror image to the verification principle. Rather, Flew 'simply challenged religious believers to explain how their statements are to be understood, especially in the light of conflicting data. The paper elicited numerous responses ... many of which helped me to sharpen - and at times, correct - my views.' ${ }^{38}$ For example: 'Basil Mitchell, who succeeded C.S. Lewis as President of the Socratic Club, said that . . . the theological problem of evil arose precisely because the existence of pain seems to count against the truth that God loves humankind.' ${ }^{49}$ By analogy, the claim that the Earth is a globe 'excludes the possibility that it is flat' 50 and:

although it may appear flat, this apparent contradiction can be explained by the earth's great size, the perspective from which we are viewing it, and so on. So, once you add appropriate qualifications, the claim can be satisfactorily reconciled with phenomena that appear to contradict it. But if contradictory phenomena and associated qualifications keep multiplying, then the claim itself becomes suspect. ${ }^{51}$

Flew eventually concluded that, like the statement 'Earth is a globe', the statement 'There is a God' is not only meaningful (since it can be 'satisfactorily reconciled with phenomena that appear to contradict it' without dying 'the death by a thousand qualifications' 52 ), but also true. ${ }^{53}$
In an article published in 1960, philosopher John Hick pointed out that, when made sufficiently precise, the statement 'God exists' is empirically verifiable, at least in principle and indirectly. In particular, he argued that 'the existence or non-existence of the God of the New Testament is a matter of fact and claims as such eventual experiential verification.' 54 Hick observed that:

a set of expectations based upon faith in the historic Jesus as the incarnation of God, and in his teaching as being divinely authoritative, could be so fully confirmed in post-mortem experience as to leave no grounds for rational doubt as to the validity of that faith. ${ }^{55}$

Hick's argument challenged the ability of the verification principle to draw a line of demarcation between meaningful 'scientific' knowledge-claims on the one hand and meaningless 'metaphysical' knowledge-claims on the other.

Unless positivism is framed broadly enough to allow the sort of indirect verification used by Hick, many explanatory claims within science would lack meaning (because they concern entities that are verified indirectly). This being so, it may be argued that the God hypothesis is not only verifiable in principle, but also in practice, since although one cannot directly verify God's existence, several arguments for theism can be framed using the same scientific form of indirect verification. As Basil Mitchell comments:

the Logical Positivist movement started as an attempt to make a clear demarcation between science and common sense on the one hand, and metaphysics and theology on the other. But work in the philosophy of science convinced people that what the Logical Positivists had said about science was 
not true, and, by the time the philosophers of science had developed and amplified their accounts of how rationality works in science, people discovered that similar accounts applied equally well to the areas which they had previously sought to exclude, namely theology and metaphysics. ${ }^{56}$

Against this historical background, the core of Montgomery's evidential apologetic, with its focus upon the historical claims and confirmatory resurrection of Jesus, might be read as a move to use historical evidence to show that Christian theism is indirectly verifiable in the here and now. As Montgomery summarizes his case in Always Be Ready:

we can set out a series of propositions that - if the evidence sustains them - lead directly to a confirmation of the Christian position. 1. The New Testament documents are solid. 2. The New Testament witnesses to Jesus are eminently reliable. 3. In these documents, Jesus predicts his resurrection from the dead and the witnesses declare that $\mathrm{He}$ in fact conquered death. ${ }^{57}$

In 1967 American philosopher Alvin Plantinga published God and Other Minds, which 'applied the tools of analytic philosophy to questions in the Philosophy of Religion with an unprecedented rigour and creativity.' $58 \mathrm{He}$ argued by analogy with the rationality of belief in other minds (whose non-tautological existence can't be directly verified by empirical methods) that if my belief in other minds is rational, so is my belief in God.'59 But, of course, even verificationists generally believe in other minds. Then, with the 1974 publication of The Nature of Necessity, Plantinga kick-started a philosophical re-evaluation of theistic arguments by using modal logic to lay out a logically valid version of the ontological argument. 60 Between them, God and Other Minds and The Nature of Necessity tackled both prongs of the positivist's proposed dilemma: Show that theism is either verifiable or tautologically true, or else accept banishment to the outer darkness of meaninglessness. Plantinga responded to the first positivist prong that a demand for direct verification renders positivism self-contradictory, thereby opening up the possibility of the sort of arguments from indirect verification employed by Hick and Montgomery. To the second prong, Plantinga responded that, even if he can't prove that God's existence is tautologically true, he can prove that it is rational to think that God's existence is tautologically true, and that this is sufficient to demonstrate that God-talk is meaningful, for how can a truth-claim be rational without also being meaningful?

Finally, supposing one has a properly basic experiential impression of the truth of various moral and aesthetic propositions (such as that human beings have value or that rainbows are beautiful): why not reject the verificationist's assertion that such claims are meaningless, quite apart from any arguments about the possibility of indirect verification, simply on the basis that the appearance that these claims are meaningful is stronger than the case for verificationism? Indeed, what is the case for verificationism?! As Ayer himself asked: 'why should anyone follow the [verificationist] prescription if its implications were not to his taste?' 61 Indeed, Ayer wrote the obituary for the movement he'd once led: 'Logical Positivism died a long time ago. I don't think much of Language, Truth and Logic is true. I think it is full of mistakes.' 62 As Hugh J. McCann observed in 2010: 'The radical claims of logical positivism . . . 
have today very few defenders . . .'63 Thus William Lane Craig explains:

The collapse of verificationism during the second half of the twentieth century was undoubtedly the most important philosophical event of the century. Its demise brought about a resurgence of metaphysics, along with other traditional problems of philosophy that had been hitherto suppressed. Accompanying this resurgence has come something new and altogether unanticipated: a renaissance in Christian philosophy. ${ }^{64}$

\section{Montgomery's Evidentialism}

While Montgomery's apologetic can be read as a rebuttal of the claim that the Verification Principle shows Christian theism to be meaningless (because indirect verification shown it to be true), it has more in common with Hick's argument from indirect verification than to the rejection of verificationism that followed in the wake of Alvin Plantinga's critique of the movement, a critique that led to a 'renaissance in Christian philosophy'65 that included a positive re-evaluation of metaphysical arguments for theism. ${ }^{66}$ That is to say, Montgomery's apologetic advice appears to be rooted in an epistemology that remains overly focused upon empirical verification.

Montgomery consequently calls upon would-be apologists to: 'Forget your wondrous, interior blessedness such as A.H. Ackley's hymn line, "You ask me how I know he lives: He lives within my heart."'67 as something 'The unbeliever will hardly be impressed by . . . since he or she can't look inside you to determine if yours is a genuine spiritual experience or heartburn or stomach trouble.' 68 Instead, says Montgomery, 'You have to present evidence outside of yourself - evi- dence that can be meaningful to the seeker. This means that apologetics is, by nature, an objective activity.' 69 Having thus dismissed evidence from religious experience as meaningless 'to the seeker', he asserts that 'Religious claims need to be tested in the crucible of factual evidence.' 70

However, it should be obvious even to third parties that other people can tell the difference between mystical, religious experience on the one hand and heartburn or stomach trouble on the other. Moreover, by what Richard Swinburne calls 'the principle of testimony', other people's reports of their first person subjective experience is at least evidence that must be taken into account, for:

individuals ought to believe the reports of others about how things seemed to them, and so (given the principle of credulity) that things were as they report - in the absence of counter-evidence. ${ }^{71}$

The problem with Montgomery's rejection of arguments from religious experience $^{72}$ runs deep, for once again we find him employing an ill-drawn philosophical distinction. This time the distinction is between 'evidence' that's 'objective' because it is found 'outside of yourself' (that is, outside of your mental self) and can therefore be 'meaningful to the seeker', and subjective evidence that's found inside your mental self and is therefore meaningless to the seeker. This distinction collapses as soon as it is presented with testimony based upon a person's memory of an event. Montgomery champions the relevance and applicability of legal reasoning to Christian apologetics, but critically assessing the subjective testimony of witnesses is an everyday occurrence in a law-court. Likewise, perceptions of moral or aesthetic reality, which may well be 
shared and found meaningful by 'the seeker', collapse Montgomery's distinction. Indeed, all arguments, including those that incorporate empirical evidence, depend upon our inner, non-empirical perception of logical laws.

Montgomery is absolutely right to point out that: 'throughout the Bible, prophets and apostles - and our Lord himself - clearly expect their audience to respond to evidence. ${ }^{\prime} 73$ However, the evidence in question can hardly be restricted to 'objective' empirical evidence, for throughout the Bible prophets and apostles and Jesus - clearly expect their audience to respond to the evidence of their 'subjective' perception of moral (and even aesthetic) facts. ${ }^{74}$ Thus, Jesus described himself as 'the kalos [i.e. beautiful-good] shepherd ...'75 and implored his disciples to 'Have faith in me when I say that the Father is one with me and that I am one with the Father. Or else have faith in me simply because of the things I do. ${ }^{76}$

Montgomery frames his search for an 'objective'77 apologetic 'worth the effort'78, able to provide humans with 'definitive conclusions'79 and 'a metaphysically compelling, comprehensive explanation of reality'80, with a confused argument for the desirability of a revelation given the inherent limitations of human knowledge:

The point here is that every secular attempt at 'knowing the universe' will lack logical or factual necessity. The only solution, in principle, is a transcendent revelation from outside the universe - that is, a word from God ... But can not this limitation be turned around and used against the apologist .. ? Does not the human inability to assert absolutes at the same time prevent any kind of effective argument for the faith? Are we not forced to accept the classical adage finitum noncapax infiniti ('the finite is incapable of the infinite'), or, even worse, Lessing's 'ditch,' which states that the accidental truths of history can never provide the necessary truths of reason? Not so, for we must distinguish carefully between a transcendental revelation and the evidence for a transcendental revelation. We are incapable (by definition) of providing the former, but we may certainly check out the claims that such a revelation exists.. If, let us say, there should be solid prophetic and miracle evidence to support Jesus' claim to deity, we are on entirely different ground, such that we can (and surely must) follow the evidence wherever it leads ... It follows that certainty in religion, including, especially, the certainty of salvation and eternal life in the presence of the God of the universe, depends squarely on a verifiable divine revelation. ${ }^{81}$

Unfortunately for Montgomery, claiming that one can ground epistemological 'certainty in religion' in empirically 'verifiable' data, whilst simultaneously asserting 'that every secular attempt at "knowing the universe" will lack logical or factual necessity' and affirming 'the human inability to assert absolutes', is self-contradictory. Ironically, Montgomery's naïve empiricism combines with his simplistic distinction between presuppositions of content and method to undermine his attempt to transcend apologetic presuppositionalism.

What Montgomery needs is an epistemology that has learnt from the problems with Cartesian rationalism without succumbing to the narrow empiricism of Hume and his positivistic / scientistic descendants. This can be done by embracing an epistemology grounded in the wisdom of epistemic trust, in the vein of 
Michael Huemer's 'Phenomenal Conservatism', Richard Swinburne's epistemological credulism and/or a 'reformed' account of 'warrant' a la Alvin Plantinga. Ironically, then, the type of epistemology Montgomery needs has been developed by the philosophers he disparages. ${ }^{82}$

It is interesting to note that Montgomery's undergraduate training in philosophy was completed in 1952, before the collapse of logical positivism and the Christian revolution in philosophy spearheaded by Plantinga. ${ }^{83}$ Perhaps this explains why Montgomery's apologetic method combines such a low opinion of philosophy with an almost positivistic dedication to empiricism.

\section{Montgomery Argues for God}

Strangely, having spent so much effort repudiating metaphysics in favour of a legal-cum-historical apologetic, and having said that he intends to 'help the fledgling apologist to understand and present the unbeliever the case for a divine revelation ...'84, Montgomery immediately turns to outlining a cosmological argument for the existence of God.

Montgomery presents 'the following series of questions that lead - inevitably to an affirmation of God's existence:

1. Do you or does anyone else know of anything in this world that can explain itself? The necessary answer is no. (This book requires an appeal beyond itself to explain it-for example, recourse to an author. And the author is not selfexplanatory; one must, at minimum, appeal to his parents to explain his presence, and so on.)

2. Would you agree that the world consists of all the stuff in it? The necessary answer (since we mean by 'the world' the sum total of all the stuff in it) is yes. (Denying such would be an admission not only of a serious hole in the head, logically speaking, but probably also of the need for immediate psychiatric help.)

3. Can the world, taken as a whole, explain itself? The necessary conclusion, based squarely on the preceding, is no.

To explain the world, then, one must go outside or beyond it for an explanation. That is to say, one must go to a transcendental source - or, in ordinary language, God to explain the universe in which we find ourselves. 85

Unfortunately, this is a logically invalid argument. From the fact that neither you nor anyone else, as far as you are aware, knows anything 'in this world' that can explain itself, it does not follow that nothing 'in this world' can explain itself, or that the world considered as the sum total of things 'in this world' cannot explain itself. Neither does it follow from the conclusion that the world has 'a transcendental source', that this source is 'God'.

Montgomery takes a different tack when he writes:

There is no evidence or reason to think that God is contingent, but there is overwhelming evidence that our world is entirely so. Thus the believer in God is a realist: he or she says, 'The universe looks contingent, smells contingent, and tastes contingent. I therefore conclude that it is contingent, requiring a transcendent explanation outside of it - namely, God.' The atheist, however, is the true mythmaker. He or she says, 'Granted, the universe looks contingent, smells contingent, and tastes contingent. But against all evidence, I believe that really, deep down, it is self-explanatory, needing no God to explain it.' Such irrationality and flying in the face of the facts would appear to 
confirm the psalmist's assertion: 'The fool has said in his heart, there is no God' (Ps. 14:1).86

This focus on the contingency of the cosmos is more to the point. That said, the cosmos doesn't literally look, smell or taste contingent! Montgomery is clearly using this empirical language to metaphorically express the contingency of physical realities that presents itself in metaphysical analysis of our empirical experience. Moreover, Montgomery blurs the distinction between the cosmos being 'selfexplanatory' and being a brute fact without any explanation, and repeats the tooeasy leap from 'transcendent explanation' to 'God'. 87

\section{On a Positive Note}

I would not wish to give the impression that there is nothing of value in this 'simple layman's primer on defending the Christian faith'.88 For example, Montgomery displays practical wisdom in reminding readers that:

we must not confuse law and gospel by first expecting the unbeliever to clean up his or her life before the gospel can mean anything to that person. Of course, one must recognize and repent of sin in order to come to Christ for forgiveness. But this hardly means cleaning up one's whole life by one's own efforts as a prerequisite for salvation. ${ }^{89}$

Likewise, Montgomery is right to point out that the traditional (i.e. 'logical') argument from evil 'does not actually support atheism', since it allows for the existence of a supernatural creator who is 'not omnipotent' or who is 'morally indifferent to human misery ... The argument from evil, therefore, is really an argument against the God of the Bible, who is both all-powerful and all-good ... .90

Again, Montgomery is right to say that: 'The only way to find out if a miracle has occurred is to get off one's derrière and go out and check the value of the historical testimony of its occurrence.' 91 That said, this statement overlooks the role of the investigator's background beliefs (their presuppositions, if you like) in their assessment of data and explanatory theories, although this issue is at least partially addressed by Montgomery's inclusion of a cosmological argument for theism in his book. 92

Turning to the legal-cum-historical assessment of historical evidence for which he's primarily known, Montgomery offers a relatively sure-footed guide to this time-honoured take on 'Christian evidences':

We can set out a series of propositions that - if the evidence sustains them — lead directly to a confirmation of the Christian position. 1. The New Testament documents are solid. 2. The New Testament witnesses to Jesus are eminently reliable. 3. In these documents, Jesus predicts his resurrection from the dead and the witnesses declare that $\mathrm{He}$ in fact conquered death. ${ }^{93}$

Time honoured though it is, Montgomery's approach ignores the development of 'Tradition Criticism'94, which uses historical 'criteria of authenticity' to establish historical facts without reference to background knowledge about the general historical reliability of the New Testament. ${ }^{95}$ In other words, Montgomery's defence of Christian evidences disregards the 'minimal facts' methodology embraced by many contemporary apologists ${ }^{96}$ (a development pioneered by philosopher and evidentialist apologist Gary R. Habermas ${ }^{97}$ ).

Montgomery asserts:

If one applies fraud analysis to the Gospel accounts (I am a CFE, a certified fraud examiner, so I am in a 
strong position to do so), they come out smelling like a proverbial rose. Cressey's 'fraud triangle' and Albrecht's 'fraud scale' identify opportunity and situational pressure, as well as low personal integrity, as the major predictors of fraud. In the case of the Gospel witnesses, none of these apply. They (except Judas) possessed high personal integrity, had no motivation to fabricate a divine picture of Jesus - just the contrary, in light of the official religious opposition to His claims to messiahship - and, most important, had no opportunity to get away with a skewed picture of Jesus when hostile witnesses of the same events were alive and more than willing to destroy the Christian claims had they been in a position to do so. ${ }^{98}$

This is an intriguing suggestion that I had not come across elsewhere; but the suggestion would require more historical argument to convincingly substantiate than Montgomery has space to provide in Always Be Ready.

In Part three, chapter three of Always Be Ready, Montgomery observes:

All of us are both a head and a heart. And those who have delved into the inner workings of the self psychoanalysts such as Carl Gustav Jung, religious sociologists such as Mircea Eliade, folklorists such as Stith Thompson, and littérateurs such as J. R. R. Tolkien - have come to the common conclusion that humans possess archetypal motifs independent of cultural borrowing that tell us much about universal inner needs. Thus the dream life and the folk tales of humanity point to a realization that we are broken and estranged, needing somehow, like Humpty Dumpty, to be put back together again. ${ }^{99}$
This is a welcome recognition of the need for a more holistic, rhetorically rounded apologetic, and one that seems to gesture towards a theistic argument from desire. ${ }^{100}$

\section{On the other hand ...}

That said, Montgomery does not develop an argument from the human heart. Instead, he merely suggests that: 'If the reader resonates at all with this - and how can it be otherwise, since we are "tenderminded" as well as "tough-minded" - are we not thereby provided with still another incentive to receive the gospel of grace?'101 Then he proceeds to offer 'The common folktale of Sleeping Beauty'102 as an illustration ${ }^{103}$ :

A wicked witch, by persuading a princess to eat forbidden fruit, causes her to fall into a deathlike trance, subjecting all those around her to a similar fate. But a prophecy comes true: a prince discovers her and gives her the kiss of love. She recovers, they are wed, and she lives happily ever after. The folktale - like much of classical mythology - is a pale reflection of the Gospel story. The wicked witch represents the devil; the princess is the human race dead in trespasses and sin; the prince is Jesus Christ who saves by His act of love for a humanity totally incapable of saving itself. 104

Unfortunately, Montgomery appears to have confused and somewhat conflated the folktale of Sleeping Beauty105 with Walt Disney's film version of Snow White and the Severn Dwarfs!

Indeed, Always Be Ready contains several false statements. For example, Montgomery states that: 'Our entire knowledge of the life and ministry of Jesus derives from the documents collected in the New Testament.' ${ }^{106}$ Not so. While most of our knowledge of the life and 
ministry of Jesus derives from the documents collected in the New Testament, some knowledge about Jesus can be gleaned from extra-biblical literature of the first and second centuries A.D, and even from archaeological evidence. ${ }^{107}$

Turning to matters of philosophical theology, Montgomery asserts that: 'Christians have no clue as to how God can be Father, Son, and Holy Spirit.' 108 He thereby ignores the fact that philosophers have proposed several metaphysical models, that while they may or may not give us a 'clue' as to how God is 'Father, Son, and Holy Spirit', at least give us a 'clue as to how God can be Father, Son, and Holy Spirit.' That is, these models purport to provide models of God's Trinitarian nature that are, at the very least, coberent. 109

Montgomery also comments that: 'Presumably, as God Almighty, [Jesus] has forgotten more about cosmic truth than any of us will ever know.'110 Presumably, this is meant as a joke; but it risks giving the impression that the incarnation made the divine nature of the Son less than omniscient.

Finally, Montgomery leaves readers with the take-home summary that:

Surely, if this Primer has demonstrated anything, it has shown that the case for historic, biblical Christianity is so powerful, and the arguments against it so feeble, that if one should ever be justified in making a religious decision, one is acting with eminent rationality to accept Jesus Christ . . .111

Regrettably, this is a textbook case of over-selling and under-delivering.

\section{Conclusion}

The guild of Christian apologetics certainly owes John Warwick Montgomery a debt of gratitude for his trendsetting evidential defense of the faith. However, we should not fail either to note or to learn from his mistakes.

I have defined Christian apologetics as the art and science of persuasively communicating and advocating Christian spirituality across spiritualties, through the responsible use of classical rhetoric, as being objectively reasonable and/or true, good and beautiful. I have also suggested that doing Christian apologetics responsibly requires the rhetorically wise (artful and loving) communication and advocation of truth, an undertaking that includes (but is not limited to) the communication of sound arguments in a style and with a level of sophistication appropriate for one's audience. ${ }^{112}$

By these criteria, I am sorry to say that Always Be Ready is, on balance, a disappointing presentation. On the plus side, it certainly communicates and advocates some truths, and some suggestive lines of argument, with a level of sophistication appropriate for its intended audience. However, some of its rhetoric seems ill advised, some of its statements are false, and some of its arguments are invalid. In particular, Always Be Ready is de-railed from the start by an unduly narrow empiricist epistemology and a self-defeating, negative attitude towards philosophy.

Hence, we can draw the valuable lesson that those who want to learn 'to do apologetics responsibly' 113 would be well advised to take whatever steps they reasonably can to become an informed, rhetorically wise and 'metaphysically acute'114 defender of the faith. ${ }^{115}$ 
1 Norman L. Geisler, quoted by Brian K. Morley, Mapping Apologetics: Comparing Contemporary Approaches (Downers Grove, Illinois: IVP Academic, 2015), 293.

2 See: Kenneth D. Boa and Robert M. Bowman Jr., Faith Has Its Reasons: An Integrative Approach to Defending Christianity, second edition (Milton Keynes: Paternoster, 2005), part three; Brian K. Morley, Mapping Apologetics: Comparing Contemporary Approaches (Downers Grove, Illinois: IVP Academic, 2015), 292-333; Benjamin K. Forrest, Joshua D. Chatraw and Alister E. McGrath ed.'s, The History of Apologetics (Grand Rapids, Michigan: Zondervan, 2020). See also: William A. Dembski and Thomas Schirrmacher, ed.'s. Tough-Minded Christianity: Honoring the Legacy of John Warwick Montgomery (Nashville, Tennessee: B\&H Academic, 2008).

3 See: Thomas Sherlock, The Trial of the Witnesses of the Resurrection of Jesus Christ (Milton Keynes: Dodo Press, 2009).

4 See: William Lane Craig, Reasonable Faith: Christian Truth and Apologetics, third edition (Wheaton, Illinois: Crossway, 2008); Gary R. Habermas, The Resurrection of Jesus: An Apologetic (Lanham: University Press of America, 1984); Gary R. Habermas and Michael R. Licona, The Case for the Resurrection of Jesus (Grand Rapids, Michigan: Kregel, 2004); Michael R. Licona, The Resurrection of Jesus: A New Historiographical Approach (Nottingham: Apollos, 2010); Peter S. Williams, 'Evidence, Explanation, and Expectation' in Carl Stecher and Craig Blomberg, with Richard Carrier and Peter S. Williams, Resurrection: Faith or Fact? (Durham, North Carolina: Pitchstone, 2019). On the combination of both methods, see: Peter S. Williams, Getting at Jesus: A Comprehensive Critique of Neo-Atheist Nonsense About the Jesus of History (Eugene, Oregon: Wipf and Stock, 2019).

5 See: Norman L. Geisler, Christian Apologetics, Second Edition (Grand Rapids, Michigan: Baker Academic, 2013); Josh McDowell, The Resurrection Factor (Sam Bernardo, CA: Here's Life, 1991); Josh McDowell \& Sean McDowell, Evidence that Demands a Verdict (Nashville, Tennessee: Thomas Nelson, 2017);

J.P. Moreland, Scaling the Secular City: A Defence of Christianity (Grand Rapids, Michigan: Baker Academic, 1987); Lee Strobel, The Case for Christ, updated \& expanded (Grand Rapids, Michigan: Zondervan, 2016) and J. Warner Wallace, Cold Case Christianity (Colorado Springs, CO: David C Cook Publishing Company, 2020).

6 See: John Warwick Montgomery, The Shape of the Past: A Christian Response to Secular Philosophies of History (Eugene, Oregon: Wipf and Stock, 2008).

7 See: John Warwick Montgomery, The Transcendent Holmes, 2nd edition (Irvine, California: NRP Books, 2015); John Warwick Montgomery ed. Myth, Allegory, and Gospel: An Interpretation of J.R.R Tolkien / C.S Lewis / G.K Chesterton / Charles Williams (Irvine, California: NRP Books, 2015).

8 See: John Warwick Montgomery, Human Rights and Human Dignity (Irvine, CA: 1517 Publishing, 2019); John Warwick Montgomery, The Law Above The Law, 2nd edition (Irvine, California: NRP Books; 2015); John Warwick Montgomery ed., Jurisprudence: A Book of Readings (Irvine, California: NRP Books, 2015). 9 See: www.apologeticsacademy.eu/Professor_John_Warwick_Montgomery.php \& https://en.wikipedia.org/wiki/John_Warwick_Montgomery.

10 John Warwick Montgomery, Always Be Ready: A Primer on Defending the Christian Faith (Irvine, CA: 1517 Publishing, 2018), 3.

11 Montgomery, Always Be Ready, back cover.

12 Montgomery, Always Be Ready, 15.

13 Alister E. McGrath, Mere Apologetics: How to Help Seekers and Skeptics Find Faith (London: SPCK, 2016).

14 For further reflection on the nature of Christian apologetics, see: Peter S. Williams, 'Apologetics in 3D', Theofilos (2016), www.peterswilliams.com/2016/02/09/apologetics-3d-peer-reviewed/; Peter S. Williams,

'The Apologetics of Cultural Re-Enchantment: Makoto Fujimura's Culture Care \& Paul M. Gould's Cultural Apologetics', Theofilos (2019/1 June / July), 79-88, www.peterswilliams.com/2019/07/11/the-apologetics-ofcultural-re-enchantment-in-3d-makoto-fujimuras-culture-care-paul-m-goulds-cultural-apologetics/.

15 Kenneth D. Boa and Robert M. Bowman Jr., Faith Has Its Reasons: An Integrative Approach to Defending Christianity, second edition (Milton Keynes: Paternoster, 2005), 157. Indeed, it's worth noting that Montgomery embraced Kurt Gödel's ontological argument for God in a 2018 paper published in the journal Philosophia Christi (Volume 20, Issue 1, 2018, Pages 197-204,

www.pdcnet.org/pc/content/pc_2018_0020_0001_0197_0204). See also: Gary R. Habermas, 'Greg Bahnsen, John Warwick Montgomery, and Evidential Apologetics'

https://digitalcommons.liberty.edu/cgi/viewcontent.cgi?article $=1108 \&$ context=lts_fac_pubs.

16 Montgomery, Always Be Ready, 15.

17 Montgomery, Always Be Ready, 13.

18 Montgomery, Always Be Ready, 4.

19 Montgomery, Always Be Ready, 7.

20 Montgomery, Always Be Ready, 29.

21 James K. Beilby and Paul Rhodes Eddy, 'The Quest for the Historical Jesus: An Introduction' in The Historical Jesus: Five Views (ed. James K. Beilby and Paul Rhodes Eddy; London: SPCK, 2010), 41.

22 Beilby and Eddy, 'The Quest for the Historical Jesus: An Introduction', 41. 
23 See: Carl Stecher and Craig Blomberg, with Richard Carrier and Peter S. Williams, Resurrection: Faith or Fact? (Durham, North Carolina: Pitchstone, 2019); Peter S. Williams, Getting at Jesus: A Comprehensive Critique of Neo-Atheist Nonsense about the Jesus of History (Eugene, Oregon: Wipf and Stock, 2019); Peter S. Williams, Understanding Jesus: Five Ways to Spiritual Enlightenment (Milton Keynes: Paternoster, 2013). 24 See: William Lane Craig, Reasonable Faith: Christian Truth and Apologetics, third edition (Wheaton, Illinois: Crossway, 2008); William Lane Craig, The Son Rises (Eugene, Oregon: Wipf and Stock, 2001); William Lane Craig, Assessing the New Testament Evidence for the Historicity of the Resurrection of Jesus (Studies in the Bible and Early Christianity) (New York: Edwin Mellen Press, 1989); Stephen T. Davis, Risen Indeed (Grand Rapids: Erdmans, 1993); C. Stephen Evans, The Historical Christ and the Jesus of Faith: The Incarnational Narrative as History (Oxford University Press, 1996); Gary R. Habermas and Michael R. Licona, The Case for the Resurrection of Jesus (Grand Rapids, Michigan: Kregel, 2004); Gary R. Habermas, The Historical Jesus: Ancient Evidence for the Life of Christ (College Press, 1996); Gary R. Habermas, The Resurrection of Jesus: An Apologetic (Lanham: University Press of America, 1984); Lydia McGrew, Hidden in Plain View: Undesigned Coincidences in the Gospels and Acts (Tampa, FL: DeWard, 2017); Richard Swinburne, Was Jesus God? (Oxford University Press, 2010); Richard Swinburne, The Resurrection Of God Incarnate (Oxford University Press, 2003).

25 See: Peter S. Williams, A Faithful Guide to Philosophy: A Christian Introduction to the Love of Wisdom (Eugene, Oregon: Wipf and Stock, 2019).

26 J.B. Phillips' translation.

27 For a development of these themes, see: Peter S. Williams, 'Why Should Christians Study Philosophy?' https://apologetics315.com/2013/08/why-should-christians-study-philosophy-by-peter-s-williams/;

Peter S. Williams, 'Apologetics in 3D', Theofilos (2016), www.peterswilliams.com/2016/02/09/apologetics3d-peer-reviewed/; 'The Apologetics of Cultural Re-Enchantment: Makoto Fujimura's Culture Care \& Paul M. Gould's Cultural Apologetics', Theofilos (2019/1 June / July), 79-88, www.peterswilliams.com/2019/07/11/the-apologetics-of-cultural-re-enchantment-in-3d-makoto-fujimurasculture-care-paul-m-goulds-cultural-apologetics/; Peter S. Williams, A Faithful Guide to Philosophy:

A Christian Introduction to the Love of Wisdom (Eugene, Oregon: Wipf and Stock, 2019).

28 C.S. Lewis, 'The Weight of Glory', www.wheelersburg.net/Downloads/Lewis\%20Glory.pdf.

29 John Wesley, ‘An Address to the Clergy' http://wesley.nnu.edu/john_wesley/10clergy.htm.

30 Douglas Groothuis, Christian Apologetics: A Comprehensive case for Biblical Faith (Downers Grove, Illinois: IVP Academic, 2011), 26, footnote 10.

31 Groothuis, Christian Apologetics, 3.

32 Montgomery's website lists his degrees as: 'Cornell (AB Dist Philosophy); California Berkeley (BLS, MA); Wittenberg Ohio (BD, STM); Chicago (PhD); Strasbourg (Docteur d'Université); International Institute of Human Rights Strasbourg (Diplôme cum laude); LaSalle (LL.B); Essex (MPhil Law); Cardiff (LL.M., LL.D.).' - www.jwm.christendom.co.uk. According to Wikipedia, Montgomery was the Distinguished Research Professor of Philosophy and Christian Thought at Patrick Henry College in Virginia, USA, from 2007 to 2014. - https://en.wikipedia.org/wiki/John_Warwick_Montgomery.

33 Montgomery, Always Be Ready, 9.

34 Montgomery, Always Be Ready, 9.

35 Montgomery, Always Be Ready, 9.

36 William Lane Craig, 'Theism Defended', in The Nature of Nature: Examining the Role of Naturalism in Science (ed. Bruce L. Gordon and William A. Dembski; Wilmington, DE: ISI, 2011), 901.

37 A.J. Ayer, Language, Truth and Logic (New York: Dover, 1952), 115.

38 Ayer, Language, Truth and Logic, 31.

39 F.C. Copleston, Contemporary Philosophy: Studies of Logical Positivism and Existentialism (London:

Burns \& Oates, 1956), 9.

40 Ayer, Language, Truth and Logic, 115.

41 Victor Reppert, C. S. Lewis's Dangerous Idea (Downers Grove, IL: IVP, 2003), 20.

42 Craig, 'Theism Defended', 902.

43 Kai Nielson, 'Naturalistic Explanations of Theistic Belief' in A Companion to the Philosophy of Religion (Oxford: Blackwell, 1999), 402.

44 A.J. Ayer, The Central Questions of Philosophy (London: Penguin, 1973), 34.

45 Luke Muehlhauser, 'The Renaissance of Christian Philosophy' http://commonsenseatheism.com/?p=6448.

For a reading of C.S. Lewis' paper 'The Language of Religion', published in Christian Reflections (Grand Rapids: Erdmans, 1967), as an argument against verificationalism, see chapter two of Peter S. Williams, C.S. Lewis vs. the New Atheists (Milton Keynes: Paternoster, 2013), 37-41.

46 Antony Flew, 'Theology and Falsification' in The Existence of God (ed. John Hick; London: Collier, 1964), 226-7.

47 Antony Flew with Roy Abraham Varghese, There Is a God (New York: HarperOne, 2007), 44-5.

48 Flew with Varghese, There Is a God, 44-5.

49 Flew with Varghese, There Is a God, 45-6.

50 Flew with Varghese, There Is a God, 43. 
51 Flew with Varghese, There Is a God, 43.

52 Antony Flew, 'Theology and Falsification', 226.

53 See: Antony Flew and Gary R. Habermas, 'My Pilgrimage from Atheism to Theism. A Discussion

between Antony Flew and Gary Habermas' www.epsociety.org/library/articles.asp?pid=33; Antony Flew with Roy Abraham Varghese, There Is a God (New York: HarperOne, 2007).

54 John Hick, 'Theology and Verification' in The Philosophy of Religion (ed. Basil Mitchell; OUP, 1971), 71.

55 Hick, 'Theology and Verification', 69.

56 Basil Mitchell, 'Reflections on C.S. Lewis, Apologetics, and the Moral Tradition: Basil Mitchell in

Conversation with Andrew Walker' in Rumours of Heaven: Essays in Celebration of C. S. Lewis (ed.

Andrew Walker and James Patrick; Guildford: Eagle, 1998), 19.

57 Montgomery, Always Be Ready, 26.

58 William Lane Craig, Philosophy of Religion: A Reader and Guide (Edinburgh University Press, 2002), 1.

59 Alvin Plantinga, God and Other Minds (Cornell University Press, 1967), 271.

60 See: Alvin Plantinga, 'The Ontological Argument'

www.lastseminary.com/ontological-argument/Plantinga \%20-\%20The\%20Ontological\%20Argument.pdf.

61 Ayer, The Central Questions of Philosophy, 34.

62 A.J. Ayer in Great Thinkers on Great Questions (ed. Roy Abraham Varghese; Oxford: Oneworld, 2009), 49.

63 Hugh J. McCann, 'The Case for Free Will' in Analytic Philosophy without Naturalism (ed. Antonella

Corrandini, Sergio Galvan and E. Jonathan Lowe; London: Routledge, 2010), 240.

64 Craig, 'Theism Defended', 902.

65 Craig, 'Theism Defended', 902.

66 See: Paul Copan, The Naturalness of Belief: New Essays on Theism's Rationality (Lanham: Lexington, 2018); William Lane Craig, Philosophy of Religion: A Reader and Guide (Edinburgh University Press, 2002); William Lane Craig and J.P. Moreland, ed.'s. The Blackwell Companion To Natural Theology (Oxford: Wiley-Blackwell, 2009); J.P. Moreland and William Lane Craig, Philosophical Foundations for a Christian Worldview, second edition (Downers Grove, Illinois: IVP, 2017); James F. Sennett and Douglas Groothuis, ed.'s. In Defence of Natural Theology: A Post-Humean Assessment (Downers Grove, Illinois: IVP, 2005); Jerry L. Walls and Trent Dougherty ed.'s. Two Dozen (or so) Arguments for God: The Plantinga Project (Oxford University Press, 2018); Peter S. Williams, A Faithful Guide to Philosophy: A Christian Introduction to the Love of Wisdom (Eugene, Oregon: Wipf and Stock, 2019).

67 Montgomery, Always Be Ready, 6.

68 Montgomery, Always Be Ready, 6.

69 Montgomery, Always Be Ready, 6.

70 Montgomery, Always Be Ready, 10.

71 Richard Swinburne, The Evolution of the Soul (Oxford: Clarendon, 1986), 13.

72 See: Peter S. Williams, A Faithful Guide to Philosophy: A Christian Introduction to the Love of Wisdom (Eugene, Oregon: Wipf and Stock, 2019).

73 Montgomery, Always Be Ready, 10.

$74 \mathrm{My}$ use of the term 'facts' is deliberate, for the fact that someone's perception of moral or aesthetic reality is their first-person perception thereof, and in that sense 'subjective', no more precludes the objectivity of the fact perceived than it does in the case of their perceiving objective empirical realities in the science lab.

On the objectivity of goodness and beauty, see Peter S. Williams, A Faithful Guide to Philosophy:

A Christian Introduction to the Love of Wisdom (Eugene, Oregon: Wipf and Stock, 2019).

75 John 10:11. See: https://biblehub.com/interlinear/john/10-11.htm \& https://biblehub.com/greek/2570.htm.

76 John 14:11 (Contemporary English Version).

77 Montgomery, Always Be Ready, 6.

78 Montgomery, Always Be Ready, 13.

79 Montgomery, Always Be Ready, 7.

80 Montgomery, Always Be Ready, 13.

81 Montgomery, Always Be Ready, 14.

82 See: CCA, 'Phenomenal Conservatism, Evidentialism, and Religious Epistemology (Dr. Chris Tucker)' https://youtu.be/LgBlLnT3h38; Michael Huemer, 'Compassionate Phenomenal Conservatism', Philosophy and Phenomenological Research 74 (2007) https://spot.colorado.edu/ huemer/papers/cpc.pdf;

William G. Lycan, 'Phenomenal Conservatism and the Principle of Credulity'

http://citeseerx.ist.psu.edu/viewdoc/download?doi=10.1.1.434.5879\&rep=rep1\&type=pdf; Alvin Plantinga, Knowledge and Christian Belief (Grand Rapids: Erdmans, 2015); Alvin Plantinga, Warranted Christian Belief (Oxford University Press, 2000); Mitch Stokes, A Shot of Faith (to the Head): Be a Confident Believer in an Age of Cranky Atheists (Nashville: Thomas Nelson, 2012); Richard Swinburne, Is There A God? Revised edition (Oxford University Press, 2010); Peter S. Williams, A Faithful Guide to Philosophy: A Christian Introduction to the Love of Wisdom (Eugene, Oregon: Wipf and Stock, 2019).

83 William Lane Craig, 'The Revolution in Anglo-American Philosophy'

www.reasonablefaith.org/writings/popular-writings/apologetics/the-revolution-in-anglo-american-philosophy/. 84 Montgomery, Always Be Ready, 15. 
85 Montgomery, Always Be Ready, 19-20.

86 Montgomery, Always Be Ready, 20. Psalm 14:1 is here misinterpreted by Montgomery without regard for its original ethical context. See: James L. Mays, Psalms (Louisville, Kentucky: John Knox Press, 2011), 80-82.

87 For a defence of several cosmological arguments for theism, see: Peter S. Williams, A Faithful Guide to Philosophy: A Christian Introduction to the Love of Wisdom (Eugene, Oregon: Wipf and Stock, 2019).

88 Montgomery, Always Be Ready, back cover.

89 Montgomery, Always Be Ready, 52.

90 Montgomery, Always Be Ready, 55. For a response to the problem of evil, see: Peter S. Williams, A Faithful Guide to Philosophy: A Christian Introduction to the Love of Wisdom (Eugene, Oregon: Wipf and Stock, 2019).

91 Montgomery, Always Be Ready, 29. See: Peter S. Williams, Getting at Jesus: A Comprehensive Critique of Neo-Atheist Nonsense About the Jesus of History (Eugene, Oregon: Wipf and Stock, 2019), chapter one.

92 For a discussion of this issue, see: Peter S. Williams, 'Evidence, Explanation, and Expectation' in Carl Stecher and Craig Blomberg, with Richard Carrier and Peter S. Williams, Resurrection: Faith or Fact? (Durham, North Carolina: Pitchstone, 2019).

93 Montgomery, Always Be Ready, 26.

94 Darrell L. Bock, Studying the Historical Jesus: A Guide To Sources And Methods (Downers Grove, Illinois: IVP, 2002), 199.

95 See: Robert H. Stein, 'Criteria for the Gospel's Authenticity' in Paul Copan and William Lane Craig, ed.'s. Contending with Christianity's Critics (Nashville, TN: B\&H Academic, 2009); Peter S. Williams, 'Evidence, Explanation, and Expectation' in Carl Stecher and Craig Blomberg, with Richard Carrier and Peter S. Williams, Resurrection: Faith or Fact? (Durham, North Carolina: Pitchstone, 2019); Peter S. Williams, Getting at Jesus: A Comprehensive Critique of Neo-Atheist Nonsense About the Jesus of History (Eugene, Oregon: Wipf and Stock, 2019).

96 William Lane Craig, Reasonable Faith: Christian Truth and Apologetics, third edition (Wheaton, Illinois: Crossway, 2008); Gary R. Habermas and Michael R. Licona, The Case for the Resurrection of Jesus (Grand Rapids, Michigan: Kregel, 2004); Michael R. Licona, The Resurrection of Jesus: A New Historiographical Approach (Nottingham: Apollos, 2010); Peter S. Williams, 'Evidence, Explanation, and Expectation' in Carl Stecher and Craig Blomberg, with Richard Carrier and Peter S. Williams, Resurrection: Faith or Fact? (Durham, North Carolina: Pitchstone, 2019). For a combination of both methods, see Peter S. Williams, Getting at Jesus: A Comprehensive Critique of Neo-Atheist Nonsense About the Jesus of History (Eugene, Oregon: Wipf and Stock, 2019).

97 See: Gary R. Habermas, The Resurrection of Jesus: An Apologetic (Lanham: University Press of America, 1984).

98 Montgomery, Always Be Ready, 27.

99 Montgomery, Always Be Ready, 75.

100 See: Peter S. Williams, 'A Beginner's Guide to the Argument From Desire'

www.solas-cpc.org/a-beginners-guide-to-the-theistic-argument-from-desire/; Peter S. Williams, 'C.S. Lewis as a Central Figure in Formulating the Theistic Argument From Desire' Linguaculture 2, 2019, https://journal.linguaculture.ro/images/2019-2/Linguaculture\%202_2019_11_Peter\%20S\%20Williams.pdf; Peter S. Williams, 'In Defence of Arguments From Desire'

www.peterswilliams.com/2016/11/02/in-defence-of-arguments-from-desire/; Peter S. Williams vs. Gregory

Bassham, 'Part One: The Argument From Desire' in Gregory Bassham ed., C.S. Lewis's Christian

Apologetics: Pro and Con (Leiden: Brill Rodopi, 2015); Peter S. Williams, C.S. Lewis vs. the New Atheists (Milton Keynes: Paternoster, 2013); Peter S. Williams, The Case for God (Crowborough: Monarch, 1999).

101 Montgomery, Always Be Ready, 76.

102 Montgomery, Always Be Ready, 75.

103 Montgomery, Always Be Ready, 75.

104 Montgomery, Always Be Ready, 75.

105 Dr. Oliver Tearle, 'A Summary and Analysis of the Sleeping Beauty Fairy Tale'

https://interestingliterature.com/2017/09/a-summary-and-analysis-of-the-sleeping-beauty-fairy-tale/.

106 Montgomery, Always Be Ready, 25.

107 See: Peter S. Williams, 'Archaeological Evidence and Jesus' https://youtu.be/ZaGlKZqED1k; Gary R. Habermas, The Historical Jesus: Ancient Evidence for the Life of Christ (Joplin, MO: College Press, 1996); Peter S. Williams, Getting at Jesus: A Comprehensive Critique of Neo-Atheist Nonsense About the Jesus of History (Eugene, Oregon: Wipf and Stock, 2019), chapter two.

108 Montgomery, Always Be Ready, 34.

109 See: Peter S. Williams, 'Understanding the Trinity' www.bethinking.org/god/understanding-the-trinity; Peter S. Williams, Outgrowing God? A Beginner's Guide to Richard Dawkins and the God Debate (Eugene, Oregon: Cascade, 2020); William Hasker, Metaphysics and the Tri-Personal God (Oxford University Press, 2017); Brian Hebblethwaite, The Essence of Christianity: A Fresh Look At The Nicene Creed (London: SPCK, 1996); H.P. Owen, Christian Theism: A Study in its Basic Principles (Edinburugh: T\&T Clark, 1984); J.P. Moreland and William Lane Craig, Philosophical Foundations for a Christian Worldview (Downers 
Grove, Illinois: IVP, 2017); Richard Swinburne, The Christian God (Oxford University Press, 1995).

See also: Peter S. Williams, 'Sermon: Revelation 1:1-8: On Revealing the Trinity'

http://podcast.peterswilliams.com/e/sermon-revelation-11-8-on-revealing-the-trinity/.

110 Montgomery, Always Be Ready, 31.

111 Montgomery, Always Be Ready, 80.

112 For further reflection on the nature of Christian apologetics, see: Peter S. Williams, 'Apologetics in 3D', Theofilos (2016), www.peterswilliams.com/2016/02/09/apologetics-3d-peer-reviewed/; Peter S. Williams,

'The Apologetics of Cultural Re-Enchantment: Makoto Fujimura's Culture Care \& Paul M. Gould's Cultural Apologetics', Theofilos (2019/1 June / July), 79-88, www.peterswilliams.com/2019/07/11/the-apologetics-ofcultural-re-enchantment-in-3d-makoto-fujimuras-culture-care-paul-m-goulds-cultural-apologetics/.

113 Montgomery, Always Be Ready, 3.

114 Montgomery, Always Be Ready, 3.

115 See: Peter S. Williams, 'Recommended reading for aspiring apologists'

https://www.amazon.co.uk/hz/wishlist/genericItemsPage/1OU3I7M8DYEEP?sort=default 